\title{
Good corporate governance, ethnic CEO and audit fees for manufacturing companies listed on the Indonesia Stock Exchange (IDX)
}

\author{
Umi Kalsum*, Luk Luk Fuadah, Rika Henda Safitri \\ Accounting Department, Universitas Sriwijaya, Palembang, Indonesia \\ *Corresponding author email: umikalsum@unsri.ac.id
}

\section{A R T I C LE INFO}

Article history:

Available online

Keywords:

Good corporate governance, CEO

ethnic, audit fee

DOI:

https://doi.org/10.20885/jaai.vol25.i ss1.art7

\section{A B S T R A C T}

This study aims to examine the effect of Good Corporate Governance, CEO ethnicity, and Audit Fees in Manufacturing Companies listed on Indonesia Stock Exchange within the period of 2014-2018. The independent variable used in this study is Good Corporate Governance, which is represented by the variable of the Independent Commissioner, Audit Committee, Managerial Ownership, Institutional Ownership and CEO Ethnicity, while the dependent variable used is Audit Fee. This quantitative research employed the descriptive research method. The population in this study included manufacturing companies listed on the Indonesia Stock Exchange (IDX). The sampling technique used in this research is purposive sampling with certain criteria and 220 data were obtained from observations within the period of 2014-2018. The data were analyzed using multiple regression analysis with Statistical Package for the Social Sciences (SPSS) software by performing calculations and descriptive statistical tests, classical assumption tests, partial tests and determination coefficient tests. The results of this study indicate that Independent Commissioner, Audit Committee, Managerial Ownership, and CEO Ethnicity have a significantly positive impact on Audit Fees.

\section{Introduction}

Public companies and their financial statements are inseparable. Financial reports must be relevant and credible because the results of financial reports are very useful for users, such as investors, governments, the public or creditors to make decisions (Permata et al., 2019). Therefore, financial reports need to be audited by professional auditors from a Public Accountant Office (KAP) as an independent institution to ensure that the financial statements have presented true information regarding the condition of the company (Ayu \& Septiani, 2016).

In performing their duties in providing audit services to clients, Public Accounting Firms (KAP) are entitled to receive fees (Yulio, 2016). Audit fee obtained must be in accordance with the agreement between the public accountant and the client as stated in the Engagement (Sinaga \& Rachmawati, 2018). Indonesian Institute of Public Accounting (IAPI) issued Management Regulation Number 2 of 2016 concerning Audit Service Fees, which establishes a lower limit for hourly services based on the tiered classification: Junior, Senior, Supervisor, Manager, and Partner Auditor in Jabodetabek receive an hourly service fee of Rp 100,000; Rp 150,000; Rp 300,000; Rp 700,000; and Rp 1,500,000 respectively. Meanwhile Junior, Senior, Supervisor, Manager, and Partner Auditor outside Jabodetabek receive an hourly service fee of Rp 70,000; Rp 125,000; Rp 200,000; Rp 500,000; and Rp 1,200,000 respectively.

Many factors can influence the amount of external audit fees, such as Good Corporate Governance, earnings management and CEO ethnicity. Every company certainly wants to maintain its survival in the long term. Therefore, companies are required to always make improvements on corporate governance in order to increase shareholder trust from both domestic and foreign parties. This is known as Good Corporate Governance (GCG). Good GCG implementation will improve company performance, which will provide added value to all interested parties and increase company value that can provide information that attracts investors in the market. Then, trust and effective communication are provided to the public and lead to a more stable going concern.

Despite the importance of Good Corporate Governance, the implementation is still a major problem in many companies because the governance has not been implemented optimally, resulting in various cases of accounting scandals (Permata et al., 2019), such as the misconduct of earnings management by Enron Corporation, Tyco and WorldCom. In Indonesia, there are similar cases, such as PT. Lippo Tbk., PT. Kimia Farma Tbk., PT. Kereta Api Indonesia and PT. Jatisari.These cases will not happen if the companies implement good corporate governance. 
One of the reasons why Good Corporate Governance is not implemented optimally is the existence of parties which have certain interests by dint of the separation between owner ownership and management ownership. Agencies want to control the interests of public shareholders. Consequently, there is always an intention of managers to act based on their own interests to report inappropriate financial results for opportunistic reasons, even at the expense of shareholders. This can complicate and hinder the company from achieving positive performance in order to generate value that is useful for all parties. This conflict of interest is the starting point of a decreasing quality indication on GCG in a company. Therefore, it is necessary to have an independent auditor to separate the relationship between control and ownership between managers and shareholders, and to provide reliable results (Arista, 2018).

Audit activities require expenses in the form of an audit fee. The amount of audit fees given is based on the policy of either party or an agreement between the public accounting firm and its client. There are four corporate governance mechanisms that are often used in various studies on corporate governance that aim to reduce agency conflicts, namely independent commissioners, audit committees, institutional ownership, and managerial ownership.

The existence of an independent commissioners aims to protect the rights of minority shareholders or other related parties. The assessment of independent commissioners are considered independent and impartial to the company because independent commissioners have no interest in the company (Prayugi, 2015). The existence of an independent commissioner on the board of commissioners is one of the requirements for a company to create good corporate governance that can reduce agency conflicts because it can reduce the risk of failure of the board of commissioners in carrying out its functions towards the board of directors and management. Therefore, independent commissioners will use the best auditor services to satisfy the interests of stakeholders. High quality audit reports require longer time and higher auditor skills so that the audit fee will increase. Previous research on the existence of independent commissioners on audit fees was conducted by Salehi et al. (2018), which indicated that independent commissioners have a significantly positive impact on audit fee.

Audit committee is a committee formed by and responsible to the board of commissioners in helping to carry out the duties and functions of the board of commissioners. Audit committee is one of the components in corporate governance that plays an important role in the financial reporting process by overseeing the work of auditors and assisting the duties of the board of commissioners. So, to create good governance, audit committee members need to have expertise and skills in accounting and finance. Audit committee members who have high expertise will easily detect wrong procedures and minimize the audit risk, thus reducing the audit fee. Previous research on the effect of audit committee on audit fees was conducted by Umar et al. (2018). He stated that audit committee has a negative influence on the audit fee, while the research conducted by Yulio (2016) stated that audit committee has a positive effect on audit fee.

Managerial ownership contributes to resolving agency conflicts and reducing agency costs. This leads to further limited actions by management related to morale and work more optimally, including the presentation of financial statements. The presentation of quality financial statements can reduce agency costs in the form of audit fees as a result of fewer auditor works. Previous research on the effect of managerial ownership on audit fees was conducted by Harahap and Prasetyo (2018), indicating that managerial ownership has a significantly negative effect over audit fee while Oktorina and Wedari (2015) claimed that managerial ownership has a significantly positive effect on audit fee.

Institutional ownership, in agency theory, influences firm policy and control within the framework of agency conflict. The greater percentage of shares owned by institutional investors, the more effective monitoring will be, through controlling the manager opportunistic behavior. Therefore, managers tend to be more careful and more focus on company performance so that it will reduce opportunistic behavior and limit managers to manage earnings. The diminishing management's intention to manage earnings will certainly ensure the owners' rights to obtain relevant and reliable financial reports. Previous research on institutional ownership of audit fees was conducted by Mitra et al. (2007) which showed that institutional ownership has a positive effect on audit fees, while research conducted by Wedari (2015a) indicated that institutional ownership has no effect on audit fees.

The next factor that could affect the audit fee is CEO's ethnicity. Ethnicity has an important role in influencing the character and economic behavior of a company. Ethnicity is grouped as a capital that cannot be measured directly to become an economic capital (Wibowo, 2012). The CEO ethnicity will affect the company's culture, where the CEO's perspective and mindset can determine individuals' actions in overcoming problems, interacting with others, managing time and doing task to increase the company performance. Research on the effect of CEO ethnicity on audit fees was conducted by Wibowo (2012), indicating that companies controlled by indigenous ethnic groups were considered to have poor corporate governance compared to ethnic descendants. Consequently, audit fee given would be lower.

Because of the absence of common ground of all the research results above, it is therefore interesting to do this research. In addition, the different results from the research above attract the author to re-examine whether the structure of corporate governance, earnings management and CEO ethics have an effect on audit 
fees. This research is a replication of the research conducted by Farooq, Muhammad Umar et al (2018). The population of this study included manufacturing companies listed on the Indonesia Stock Exchange because data from the Global Study on Occupational Fraud and Abuse conducted by the Association Of Certified Fraud Examiner (2018) show that the manufacturing sector has the biggest number of fraud cases, which is $51 \%$ (212 cases of fraud with a median loss of $\$ 240,000$ ).

Based on the background described above, the title of this study is "Good Corporate Governance (Independent Commissioner, Audit Committee, Institusional Ownership, Managerial Ownership), Ethnic CEO and Audit Fee in Manufacturing Companies Listed on the Indonesia Stock Exchange." This research addresses the following research questions: How does independent commissioner boards affect the audit fee? How does audit committee affect the audit fee? How does managerial ownership affect the audit fee? How does institutional ownership affect the audit fee? How does the ethnicity of the CEO affect the audit fee?

\section{Literature Review}

\section{Agency Theory}

Agency theory broadly explains that there is a relationship between the principal and the agent, in that the owner (principal) binds the other party who is the agent to work for them by providing services and information (Jensen \& Meckling, 1976). Information must be processed accurately and in a timely manner by the agent as a form of accountability to the owner because it will be used by the owner (principal) in making decisions. However, the existence of a separation between shareholders and management ownership creates differences in interests between principal and agent and sometimes creates agency problems or conflicts. The agent wants to control the interests of shareholders to be used publicly in various countries (Holderness, 2009). This resulted in the intention of managers to act in their own interests in order to report inappropriate financial results for opportunistic reasons, even at the expense of shareholders (Jensen \& Meckling, 1976). Priharta (2017) claimed that agency conflict that arise between various parties who have multiple interests can complicate and hinder the company to achieve best performance and generate useful value for all parties.

Agency theory describes two types of agency conflict, namely: type 1 agency conflict between shareholders (owners) and managers (control) and type 2 agency conflict between non-controlling and controlling shareholders, which is higher than Porta et al. (1999). Agency theory also offers a conceptual framework by reducing agency conflicts between managers and shareholders, including audit fees. Audit fees is remuneration for the amount of audit services requested by the managers of the audited company provided by the audit firm (Simunic, 1980).

Independent audit is a function that separates the extent of the relationship between control and ownership. If both the company structure and the financial statements seem messy or less relevant, the auditor will need more effort and time to complete the audit. This is because the independent auditor doubts the client and it will increase substantive testing to the extent necessary (Chan et al., 1993). The greater effort and time required by the auditors to complete the task, the higher the audit fees (audit fees). Audit costs will reduce company profits which in turn will reduce bonuses for managers. Therefore, managers will use their experience and expertise to organize, compile, and report on activities within the company. Thus, auditors will put less effort and time in providing audit services to the company which results in a reduction of audit fees charged to the company.

Agency theory also states that aspects of corporate governance such as managerial ownership, institutional ownership, the proportion of independent commissioners, and the number of members of the audit committee are seen as an appropriate control mechanism to reduce agency conflicts (Permata et al., 2019).

\section{Good Corporate Governance}

Global competition has pushes companies to improve their strategies to survive; one of them is by increasing the capital from external investors. Companies depend on external investors (equity loans) in order to meet financing activities, investment and company growth (Karo \& Perlantino, 2017). Companies are responsible for ensuring external investors with the implementation of good corporate governance. Corporate governance has various mechanisms:

\section{Independent board of commissioners}

According to agency theory, companies with good corporate governance are expected to reduce agency conflicts, including the existence of an independent board of commissioners. An independent board of commissioners is an organization within a company whose members are from external parties and have no relationship with the company which functions to assess company's performance (Savitri, 2016).

The existence of an independent board of commissioners in the board of commissioners is one of the requirements to create good corporate governance that can reduce agency conflicts because the existence of an 
independent commissioner can reduce the failure risk of the board of commissioners in carrying out its functions towards the board of directors and management. The government has regulated the independent board of commissioners in the Financial Services Authority Regulation Number 33 /POJK.04/2014 concerning the Board of Directors and Board of Commissioners of Issuers or Public Companies; it states that; 1) The board of commissioners consists of 2 (two) members of the board of commissioners, 1 (one) of whom is an independent commissioner. 2)If the board of commissioners consists of more than 2 (two) members of the board of commissioners, the number of independent commissioners must be at least 30\% (thirty percent) from the total members of the board of commissioners.

\section{Audit committee}

According to Indonesia Financial Services Authority Regulation Number 55 / POJK.04 of 2015, audit committee is a committee formed by and responsible to the board of commissioners in helping to carry out the duties and functions of the board of commissioners. Audit committee is chaired by an independent commissioner, where the independent commissioner is a member of the board of commissioners who comes from outside the issuer or public company, and meets the requirements referred to the regulation of the financial services authority. Indonesia Financial Services Authority Regulation Number 55 / POJK.04 / 2015 also established the number of audit committee members which consists of at least 3 (three) members from independent commissioners, and parties from outside the issuer or public company.

Audit committee is one of the components of corporate governance that plays an important role in financial reporting process by overseeing the work of independent auditors in the financial reporting process and assisting the duties of the board of commissioners (Verawati \& Wirakusuma, 2016). Audit committee must interact with external and internal auditors. Besides, audit committee should recheck the suitability of financial statement with standards and policies, also the financial statement's consistency with various information known by audit committee (Sitompul, 2017).

Klein (2002) proved that company with audit committee will report their profit with lower accrual discretionary compared to company which does not have audit committee. The accrual discretionary content is related to company profit quality (Arista, 2018).

\section{Managerial ownership}

Managerial ownership is the percentage of ownership owned by company internal parties. Managerial ownership will align management and shareholders interest because management concurrently the manager and owner so he will feel the impact of the decisions taken. (Pambudi \& Ghozali, 2013)

Referred to agency theory, managerial ownership give contribution in resolving agency conflict and reducing agency cost (Desender \& Aguilera, 2012). The alignment of interests between managers and shareholders is explained by the convergence of interests hypothesis (Morck et al., 1988). Management which has an ownership in company will restrict deviant behavior, like earning management to fulfill individual interest. The management will perform maximally to increase company performance reflected by company financial statement. One of the examples is by reducing agency theory (in this case, auditor is an agent).

External parties, both investors and shareholders usually feel that managers with large shareholdings are able to work optimally to increase the company value and performance. The greater the manager's shareholdings in the company, the lower the agency cost paid by the company.

\section{Institutional ownership}

Institutional ownership is shareholding ownership by government, finance institution, law institution, foreign institution, trust funds and other institutions at the end of the year (Istiantoro et al., 2017). Greater percentage shareholding owned by institutional investor will influence the monitoring process, which becomes more effective through management opportunistic behavior Wedari (2015a). Institutional investor is one of the important parties doing the supervisory function carried out by management in order to maintain proper financial reports.

Institutional ownership in agency theory affects company policies and control agency conflicts (Akbar \& Ruzikna, 2017). Institutional ownership has a function to acknowledge market condition better than other investors in order to assess management performance objectively (Grinstein \& Michaely, 2005). Consequently, managers tend to be careful and focus on company performance to reduce opportunistic behaviour dan restraint managers to manage earnings (Arista, 2018). Reduced management's intention to manage earnings will certainly ensure the owners' rights to obtain relevant and reliable financial reports. 


\section{CEO ethnicity}

According to the Indonesian Big Dictionary (KBBI), ethnicity is a group in a social system deriving from the same ancestry, customs, and so on. The culture formed differently from one ethnicity to another. The culture formed is important because culture shapes the perspectives, thoughts, behavior and beliefs of each individual.

Research conducted by Kirkman et al. (2006) showed that ethnicity affects individual perceptions, behaviors and beliefs. Each ethnicity has special characteristics that separate them from other ethnicities. There are ethnicities known for their persistence, calculation, strong cooperation, generosity, and other traits, both positive and negative. The diversity of each ethnicity also creates different perspectives and mindsets. The perspective and mindset can determine a person's actions in overcoming problems, interacting with others, and managing time to lead an organization or company.

CEO or Chief Executive Officer is a trusted and competent individual to lead the company board. The quality of CEO can be seen from their mindset and point of view to lead their staff, that will guide to good performance reflected by financial statements.

\section{Audit fee}

Audit fee refers to the amount of fee received by the auditor as compensation for providing services performed based on factors such as level of expertise, and many other factors. Compensation for this service is related to the amount of time used to complete the work and the value of the service provided to the client or company. The amount of audit fees that can be received by each auditor also varies, depending on the size of the company, the auditor's specialization, and others. Hoitash et al. (2007) found that when auditors negotiate with management regarding the fees paid in relation to their work, it is likely that there will be clear trade-offs that will reduce the quality of the statements being audited.

\section{Previous Research}

Umar et al. (2018) claimed that effective board quality (measured by board size, board independence, CEO duality, chairman independence, board shareholders and board persistence) positively affects audit fees, while audit committee effectiveness (measured by audit committee, audit committee independence and audit committee persistence) will reduce the audit fee.

Harahap and Prasetyo (2018) demonstrated that foreign ownership, government ownership and profitability have a significantly positive effect on audit fees, and higher managerial ownership also has a significantly negative effect on audit fees, while complexity, current ratio and leverage do not have a significant effect on audit fees.

Salehi et al. (2018) claimed that independent commissioners and managerial ownership do not have an effect on audit fee, while CEO incentive and executive incentive have a significant effect on audit fee, vega incentive have a positive effect on audit fee, nevertheless delta incentive do not have an effect on audit fee.

Nawaiseh et al. 2019) found that institutional ownership and family control ownership have a positive effect on audit fee and government ownership don't have an impact audit fee.

\section{The Influence of Independent Commissioners on Audit Fee}

Companies can create good corporate governance with the existence of independent commissioners who are external parties as these independent commissioners have no interest in the company and can reduce agency conflicts, which will reduce the failure risk of the board of commissioners in carrying out its functions towards the board of directors and management.

The independent commissioners on the board of commissioners will certainly work as much as possible, that can be seen from the quality of the audited financial reports. Independent commissioners will use the best auditor services to satisfy the interests of stakeholders. Audit reports with high quality certainly require longer time and also high-skilled auditors so, the audit fee will increase. Research conducted by Salehi et al., (2018) also stated that independent commissioners have a positive effect on audit fees

$\mathrm{H}_{1}$ : The Independent Board of Commissioners has a positive effect on audit fee.

\section{The Influence of Audit Committee on Audit Fee}

Audit committee is formed in order to detect some mistakes in the financial reporting process, and monitor the relationship between company management and auditors (Abott et al., 2003). The formation of an audit committee in a company must be properly guided from its function, role to the number of members on audit committee. The role of each member must be adjusted to the company's activities. The number of committee members must be in accordance with the complexity of a company or organization in order to work effectively. 
Based on agency theory, audit committee can reduce agency costs incurred. Audit committee has a contribution in the company to improve the integrity of financial statements. According to Widosari and Rahardja (2012), contribution made by audit committee is expected to assist the audit process carried out by the auditors so as to accelerate the completion of the audited financial statements. Less difficulty in conducting audits and less time spent by auditors influences lower audit fee.

Research conducted by Umar et al.(2018), and Oktorina and Wedari, 2015) align with the description above, stating that audit committee has a negative effect on audit fee.

$\mathrm{H}_{2}$ : Audit committee has a negative effect on audit fee.

\section{The Influence of Managerial Ownership on Audit Fee}

Managerial ownership equates the position between management and shareholders in terms of interests because management has a role as manager and owner. Consequently, the decisions and actions taken by management will directly affect their own interests.

According to agency theory, managerial ownership contributes to resolving agency conflicts and reducing agency costs. Management will restrict behavior related to morale and will perform optimally. This can be seen on the presentation of financial reporting (Desender \& Aguilera, 2012). The quality financial statement could reduce agency theory in the form of audit fee. Research conducted by Harahap and Prasetyo (2018) supports the statement that managerial ownership has a negative effect on audit fee

$\mathrm{H}_{3}$ : Managerial ownership has a negative effect on audit fee.

\section{The Influence of Institutional Ownership on Audit Fee}

Institutional ownership is shareholding ownership by government, finance institution, law institution, foreign institution, trust funds and other institutions at the end of the year (Istiantoro et al., 2017). Institutional ownership also has a monitoring function over activities that occur within the company because they have an interest in the company in the form of share capital. Institutional investors are considered to have better monitoring capabilities over management actions than individual investors (Arista, 2018).

The relationship between institutional ownership and agency theory is in the behavior of managers who tend to be careful and focus their attention on company performance. In addition, institutional parties certainly want the best, starting from company performance to reporting performance in financial reports. Institutional parties in order to maintain the quality of financial statements will use professional auditors as agents. The higher auditor's ability or experience, the higher the audit fee which must paid by the company.

This statement is in accordance with the research conducted by Mitra et al. (2007), indicating that institutional ownership has a positive effect on audit fee.

$\mathrm{H}_{4}$ : Institutional ownership has a positive effect on audit fee.

\section{The Influence of CEO Ethnicity on Audit Fee}

Culture is important because it has an influence on individual performance through perspectives, as well as different preferences regarding management and leadership related to cultural backgrounds and habits. The CEO of a company is someone who creates a culture in the company as a value system that exists in individuals; then, this value grows within the company and is used as a system for strengthening corporate governance. The culture they create is transformed into company slogans that all employees must have and internalize (Wibowo, 2012).

The ethnic existence of the company will affect the company culture. There are differences in the success of internal corporate governance between companies controlled by the majority and minority ethnic groups. H5: CEO Ethnicity has a positive effect on audit fee.

\section{Research Method}

Multiple regression analysis was used to test the variable ability of the Independent Commissioner Board of Commissioners (X1), Audit Committee (X2), Managerial Ownership (X3), Institutional Ownership (X4) and CEO Ethnicity (X5) in influencing the Audit Fee (Y). The equation is formulated as follows:

$\mathrm{Y}=\alpha 0+\beta 1(\mathrm{DKI})+\beta 2(\mathrm{KA})+\beta 3(\mathrm{KM})+\beta 4(\mathrm{KIN})+\beta 5(\mathrm{CEO})+\mathrm{e}$

Explanation:

Y : Audit Fee

$\alpha 0 \quad$ : Constanta

$\beta 1-\beta 5$ : Regression Coefficient

DKI : Independent Commissioner Board 


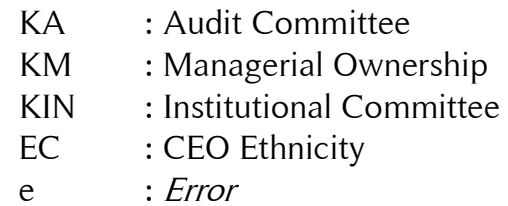

\section{Data and Sample}

The data collection method used in this research is documentation study method, in which data were obtained in the form of annual reports issued by manufacturing companies within the period of 2014-2018. Data were obtained through a website owned by the IDX, namely www.idx.co.id. The number of final samples was 220 based on firm-year observation.

\section{Variable Operationalization}

The dependent variable used in this research is audit fee. Audit fee is measured by calculating the natural logarithm of the total value of audit fees paid to external auditors (Harahap \& Prasetyo, 2018). Meanwhile, the independent variable consists of several variables, including Good Corporate Governance with Independent Board of Commissioners variable (X1) measured by calculating proportion of the number of independent commissioners in a company each year. The calculation of independent commissioners aligns with the calculation in Harymawan et al. (2020). Audit Committee Variable (X2) is a body formed by the board of commissioners in order to assist its duties and functions. The calculation of the audit committee is measured by counting the number of audit committee members in a company (Verawati \& Wirakusuma, 2016). Managerial Ownership (X3) is measured by calculating the percentage of shares owned by management (directors, board of commissioners and managers involved in decision making). This study measures managerial ownership using the calculations used in the research by Oktorina and Wedari (2018). Institutional ownership variable (X4) is measured by calculating the percentage of shares owned by other institutions such as insurance companies, banks, investment companies and other institutional ownership.

CEO Ethnicity (X5) mainly uses ethnicities in Indonesia, specifically Javanese, Chinese, and Batak ethnicities because these three ethnics are easy to identify by looking at data and profiles of the CEO in the company's annual report and these three ethnics include the majority and minority ethnic groups which are estimated to have an effect on the tested variables. Classification of ethnicity in this study can be seen in Table 2 .

Table 2. Indonesian Ethnics Used in This Research

\begin{tabular}{clll}
\hline Number & Ethnic Type & Group & Percentage \\
\hline 1. & Javanese & Majority & $40,22 \%$ \\
2. & Chinese & Minority & $1,2 \%$ \\
3. & Batak & Minority & $3,58 \%$ \\
\hline
\end{tabular}

Variable measurement was done by using dummy variable. Chinese and Batak ethnic groups who are minorities and other ethnic minorities are given code 1. Meanwhile, Javanese and other majorities are given code 0 . This measurement adopts the method of measurement used by Harjoto et al. (2015) in his research.

\section{Analysis Technique}

The analysis technique used in this research is multiple linear regression by descriptive statistical testing, classical assumption testing, hypothesis testing using a partial test ( $\mathrm{t}$ test), and testing the coefficient of determination (R2).

\section{Results and Discussion}

\section{Descriptive Statistics}

Table 3. Descriptive Statistics Test Results

\begin{tabular}{cccccc}
\hline & $\mathrm{N}$ & Minimum & Maximum & Mean & Std. Deviation \\
\hline $\mathrm{X}_{1}$ & 220 & 30.00 & 83.00 & 39.9364 & 10.15251 \\
$\mathrm{X}_{2}$ & 220 & 3.00 & 7.00 & 3.8000 & 1.21482 \\
$\mathrm{X}_{3}$ & 220 & 0.00 & 89.23 & 2.3266 & 13.35517 \\
$\mathrm{X}_{4}$ & 220 & 32.93 & 871.76 & 94.9285 & 120.20358 \\
$\mathrm{X}_{5}$ & 220 & 0.00 & 1.00 & 0.2591 & 0.43913 \\
$\mathrm{Y}$ & 220 & 12.23 & 24.57 & 18.2019 & 3.20301 \\
Valid N (listwise) & 220 & & & & \\
\hline
\end{tabular}


The results of descriptive statistics from 220 research samples in the Table 3 show the following data: Independent Commissioner (X1) variable has a minimum value of 30.00 and a maximum value of 83.00. The average value of Independent Commissioner (X1) variable is 39.94; Audit Committee variable $\left(\mathrm{X}_{2}\right)$ has a minimum value of 3.00 and a maximum value of 7.00. The average value of audit committee $(\mathrm{X} 2)$ variable is 3.8; Managerial ownership (X3) variable has a minimum value of 0 and a maximum value of 89.23 . The average value of managerial ownership (X3) variable is 2.32; Institutional Ownership $\left(\mathrm{X}_{4}\right)$ variable has a minimum value of 32.93 and a maximum value of 871.76 . The average value of institutional ownership $\left(\mathrm{X}_{4}\right)$ is 94.93 ; CEO Ethnicity $\left(\mathrm{X}_{5}\right)$ variable has a minimum value of 0 and a maximum value of 1 . The average value of CEO ethnicity $\left(\mathrm{X}_{5}\right)$ is 0.26; and Audit Fee (Y) variable has a minimum value of 12.23 and a maximum value of 24.57. The average value of audit fee $(\mathrm{Y})$ is 18.20 .

\section{Classic Assumption Test}

From the normality test with the One-Sample Kolmogorov-Smirnov Test, the data in this research are normally distributed with the Asymp.Sig. (2-Tailed) $>0.05$, which is equal to 0.200 . The value of the tolerance indicates that the 3 independent variables have a tolerance $>0.10$ and the VIF (Variance Inflation Factor) value $<10$. This shows that the regression model in this research does not have multicollinearity or there is no relationship between variables independent on this research. The results of the heteroscedasticity test using the Geljser test indicate that the significance value of all research variables is above $0.05(>0.05)$. So, it can be concluded that the regression model does not contain heteroscedasticity.

The linearity test results obtained from Deviation value from Linearity of $0.116<0.05$, which means there is no significant linear relationship between Independent Board of Commissioners variable (X1) and the Audit Fee variable $(\mathrm{Y})$; the Deviation from Linearity value is $0.364>$ from 0.05 which means that there is a significant linear relationship between Audit Committee variable (X2) and Audit Fee variable (Y) ; the Deviation from Linearity value is $0.102>0.05$, which means that there is a significant linear relationship between Managerial Ownership variable $(\mathrm{X} 3)$ towards Audit Fee $(\mathrm{Y})$ variable ; the Deviation from Linearity value is $0.340>0.05$, which means that there is a significant linear relationship between Institutional Ownership (X4) variable and Audit Fee (Y) variable; and the Deviation from Linearity value is $0.589>$ from 0.05 , which that means there is a significant linear relationship between CEO Ethnic variable (X5) and variable Audit Fee (Y).

The results of regression testing aim to determine and analyze the magnitude of relationship between independent variables and dependent variable. The ultimate goal of regression analysis is to determine the coefficient on each independent variable. In this case, the coefficient can be seen and taken by making predictions on dependent variable in a formula. In this study, $\mathrm{Y}$ used as the dependent variable and $\mathrm{X} 1, \mathrm{X} 2$, and $\mathrm{X} 3$ as independent variables. The results of multiple linear regression analysis are presented in Table 4.

Table 4. Multiple Linear Regression Analysis Test Results

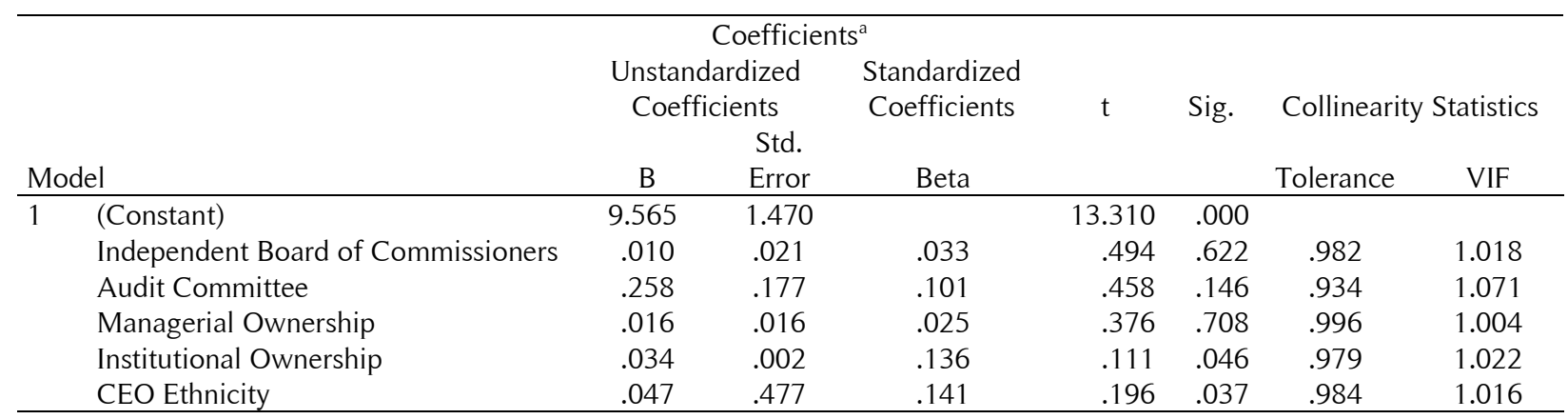

The partial test (t test) results show that Independent Board of Commissioners variable (X1) has a significant positive effect on the Audit Fee $(\mathrm{Y})$. This can be determined by looking at the coefficient on the variable, namely 0.010 , which is positive. This means Audit Fee has a positive influence and the significance of this variable is 0.000 (less than 0.05), which means that Independent Board of Commissioners has a significant effect on the Audit Fee.

Audit committee variable (X2) has a significant impact on Audit Fee (Y). This can be seen from the value of variable coefficient, namely 0.258 and positive, which means that Audit Committee has a positive influence and the value of Sig. of this variable is 0.000 (less than 0.05). This means that this variable has a significant effect.

Managerial ownership variable (X3) has a significant impact towards Audit Fee (Y). This can be seen from the value of variable coefficient, namely 0.016 and positive, which means that Managerial Ownership has a 
positive influence and the value of Sig. of this variable is 0.000 (less than 0.05 ). This means that this variable has a significant effect.

Institutional ownership variable $\left(\mathrm{X}_{4}\right)$ has a significant impact towards Audit Fee $(\mathrm{Y})$. This can be seen from the value of variable coefficient, namely 0.016 and positive, which means that Institutional Ownership has a positive influence and the value of Sig. of this variable is 0.000 (less than 0.05 ). This means that this variable has a significant effect.

CEO Ethnicity Variable (X5) has a significantly positive effect on the Audit Fee (Y). This can be determined by looking at the coefficient on the variable, namely 0.047 and positive, which means that CEO ethnicity has a positive influence and the value of Sig. of this variable is 0.000 (less than 0.05 ). This means that CEO's Ethnicity has a significant effect on the Audit Fee.

Based on these results, it can be concluded that Good Corporate Governance (GCG) variable which consists of an independent board of commissioners, audit committee, managerial ownership, institutional ownership, CEO ethnicity affects Audit Fee. An effective board of commissioners will have an influence on audit fee, the effectiveness of audit committee will also have an influence on audit fee. High managerial ownership will have an influence on audit fee (Harahap \& Prasetyo, 2018; Nawaiseh et al., 2019; Oktorina \& Wedari, 2015; Salehi et al., 2018).

For the results of determination coefficient test $\left(\mathrm{R}^{2}\right)$, the adjusted $\mathrm{R}^{2}$ value is 0.750 . This shows the ability from the five variables, specifically Independent Commissioner, Audit Committee, Managerial Ownership, Institutional Ownership, and CEO Ethnicity in explaining $75 \%$ of the variance of dependent variable, Audit Fee. Meanwhile, the remaining $25 \%$ of the variance of the dependent variable cannot be explained by independent variables in this research model. This is due to the presence of other influencing factors which are not examined in this study.

\section{Conclusion}

This study examines the effect of Good Corporate Governance represented by the variables of Independent Commissioner, Audit Committee, Managerial Ownership, Institutional Ownership and CEO Ethnicity on Audit Fee in manufacturing companies. Data were obtained from 220 samples within the period of 2014-2018. Based on descriptive statistical calculations and the classical assumptions examinations, it is known that the data met the test requirements. The results of hypothesis testing with partial test show that independent board of commissioners and CEO ethnicity variables have a significantly positive effect on audit fee; audit committee variables, managerial ownership, and institutional ownership also have a significant effect on the audit fee. This result is also in line with the $\mathrm{R}^{2}$ test where the five independent variables are able to explain the variance of the dependent variable, namely audit fee.

Limitations in this study include the disclosure of audit fees by companies because audit fees that are disclosed indirectly do not reflect the amount of audit fees. It is because there are other costs besides audit fees, also called non-audit fees, and disclosure of audit fees is still voluntary while all go public companies are required to be audited. This means audit fee is not compulsory to disclose. It is recommended that further research re-tests or even adds other variables with more companies, and use different years to ensure that there are other factors that can influence the decision in giving audit fees.

\section{References}

Abbott, L. J., Parker, S., Peters, G. F., \& Raghunandan, K. (2003). The association between audit committee characteristics and audit fees. Auditing A Journal of Practice \& Theory, 22(2), 17-32. https://doi.org/10.2308/aud.2003.22.2.17

Akbar, D., \& Ruzikna. (2017). Pengaruh struktur kepemilikan, free cash flow, struktur aset, dan kebijakan dividen terhadap kebijakan hutang pada perusahaan sub sektor otomotif dan komponen yang terdafar di Bursa Efek Indonesia (BEI). Jurnal Online Mahasiswa Fakultas IImu Sosial Dan IImu Politik Universitas Riau, 4(2), 1-11.

Arista, S. (2018). Pengaruh struktur corporate governance dan audit tenure terhadap intergritas laporan keuangan. Akuntabilitas: Jurnal Penelitian Dan Pengembangan Akuntansi, 12(2), 81-98.

Ayu, P. P., \& Septiani, T. (2016). Pengaruh ukuran dewan komisaris, komite audit, dan KAP terhadap fee audit eksternal. Jurnal Akuntansi, 12(1), 1-15.

Chan, P., Ezzamel, M., \& Gwilliam, D. (1993). Determinants of audit fees for quoted UK companies. Journal of Business Finance \& Accounting, 2066), 765-786.

Desender, K. A., \& Aguilera, R. V. (2012). When does ownership matter? Board characteristics and behavior f. 
Strategic Management Journal, 34(7), 823-842.

Grinstein, Y., \& Michaely, R. (2005). Institutional holdings and payout policy. The Journal of Finance, 60(3), $1389-1426$.

Harahap, J. O., \& Prasetyo, A. B. (2018). Ownership structures and characteristics influence on audit fees. Journal of Economics, Finance and Accounting, 5(2), 160-167. https://doi.org/10.17261/Pressacademia.2018.822

Harjoto, M., Laksmana, I., \& Lee, R. (2015). Board diversity and corporate social responsibility. Journal of Business Ethics Volume 132, Pages (2015), 132, 641-660.

Harymawan, I., Putra, F. K. G., Ekasari, W. F., \& Sucahyati, D. (2020). Are independent commissioners able to mitigate higher audit fees in politically connected firms? Evidence from Indonesia. International Journal of Innovation, Creativity and Change, 8(11), 24-43.

Hoitash, R., Markelevich, A., \& Barragato, C. A. (2007). Auditor fees and audit quality. Managerial Auditing Journal, 22(8), 761-786.

Holderness, C. G. (2009). The myth of diffuse ownership in the United States. Review of Financial Studies, 22(4), 1377-1408. https://doi.org/10.1093/rfs/hhm069

Istiantoro, I., Paminto, A., \& Ramadhani, H. (2017). Pengaruh Struktur Corporate Governance terhadap Integritas Laporan Keuangan Perusahaan pada Perusahaan LQ45 yang Terdaftar di BEI The Influence of Corporate Governance Structure to Integrity of Company 's Financial Statement to LQ45 Company Listed on IDX. AKUNTABEL, 14(2), 157-179.

Jensen, C., \& Meckling, H. (1976). Theory of the FirmL: Managerial behavior, agency costs and ownership structure. 3, 305-360.

Karo, S., \& Perlantino, J. (2017). Pengaruh corporate governance, kualitas kap, firm size, dan leverage terhadap integritas laporan keuangan pada perusahaan property dan real estate yang terdaftar di Bursa Efek Indonesia periode 2013-2015. Jurnal Akuntansi, Keuangan, Dan Perpajakan, 05(01), 102-122.

Kirkman, B. B. L., Lowe, K. B., \& Gibson, C. B. (2006). A quarter century of Culture's Consequences: A review of empirical research incorporating Hofstede's cultural values framework. Journal of International Business Studies, 37, 285-320.

Klein, A. (2002). Audit committee, board of director characteristics, and earnings management. Journal of Accounting and Economics, 33(3), 375-400.

Mitra, S., Hossain, M., \& Deis, D. R. (2007). The empirical relationship between ownership characteristics and audit fees. Review of Quantitative Finance and Accounting, 28, 257-285. https://doi.org/10.1007/s11156-006-0014-7

Morck, R., Shleifer, A., \& Vishny, R. W. (1988). Management ownership and market valuation: An empirical analysis. Journal of Financial Economics, 201), 293-315.

Nawaiseh, M. E., Bader, A., \& Nawaiseh, H. N. (2019). Ownership structure and audit pricing: Conventional versus Islamic banks in Jordan. Academy of Accounting and Financial Studies Journal, 23(2), 1-20.

Oktorina, M., \& Wedari, L. K. (2015). An empirical investigation on ownership characteristics, activities of the audit committee, and audit fees in companies listed on Indonesia Stock Exchange. Applied Finance and Accounting, 1(1), 20-29. https://doi.org/10.11114/afa.v1i1.639

Pambudi, T. L., \& Ghozali, I. (2013). Pengaruh kepemilikan perusahaan dan manajemen laba terhadap tipe auditor dan audit fees pada perusahaan manufaktur di Bursa Efek Indonesia. Diponegoro Journal of Accounting, 2(1), 1-13.

Permata, P., Fauzi, S., \& Laksito, H. (2019). Pengaruh struktur kepemilikan perusahaan terhadap biaya audit. Diponegoro Journal of Accounting, 8(2), 1-13.

Porta, R. L. A., Lopez-de-silanes, F., \& Shleifer, A. (1999). Corporate ownership around the world. The Journal of Finance, 54(2), 471-517.

Prayugi, G. (2015). Pengaruh kepemilikan perusahaan, corporate governance, dan earning management terhadap tipe auditor dan audit fees. Jurnal Akuntansi Indonesia, 4(2), 109-122. 
Priharta, A. (2017). Pengaruh corporate governance terhadap intergritasx laporan keuangan. Journal of Applied Business and Economics, 3(4), 234-250.

Salehi, M., Tarighi, H., \& Safdari, S. (2018). The relation between corporate governance mechanisms, executive compensation and audit fees Evidence from Iran. Management Research Review, 41(8), 939-967. https://doi.org/10.1108/MRR-12-2016-0277

Savitri, E. (2016). Corporate governance mechanism and the moderating effect of independency on the integrity of financial reporting. Investment Management and Financial Innovations, 13(4), 68-74. https://doi.org/10.21511/imfi.13(4).2016.06

Simunic, D. A. (1980). The pricing of audit services: Theory and evidence. Journal of Accounting Research, 18(1), 161-190.

Sinaga, E. A., \& Rachmawati, S. (2018). Besaran fee audit pada perusahaan yang terdaftar di bursa efek indonesia. Media Riset Akuntansi, Auditing \& Informasi, 18(1), 19-34.

Sitompul, F. (2017). Pengaruh mekanisme good corporate governance dan karakteristik perusahaan terhadap audit fee eksternal. Ikra-Ith Ekonomika, 2(1), 67-76.

Umar, M., Farooq, Kazim, \& Irfan. (2018). Corporate governance and audit fees: Evidence from a developing country. Pakistan Journal of Commerce and Social Sciences (PJCSS), 12(1), 94-110.

Verawati, N. M. A., \& Wirakusuma, M. G. (2016). Pengaruh pergantian auditor, reputasi KAP, opini audit dan komite audit terhadap audit delay. Jurnal Akuntansi Universitas Udayana, 17(2), 2302-8556. https://doi.org/ISSN: 2302-8556

Wedari, L. K. (2015). Aktivitas komite audit, kepemilikan institusional dan biaya audit. Jurnal Akuntansi Dan Keuangan, 17(1), 28-40. https://doi.org/10.9744/jak.17.1.28-40

Wibowo, R. H. (2012). Pengaruh struktur governance dan etnisitas terhadap fee audit (studi pada perusahaan yang listing di Indeks Kompas 100). Jurnal IImiah AKuntansi Dan Humanika, 2(1), 1-25.

Widosari, S. A., \& Rahardja. (2012). Analisis faktor-faktor yang berpengaruh terhadap audit delay pada Perusahaan consumer goods di Bursa Efek Indonesia. Universitas Diponegoro.

Yulio, W. S. (2016). Pengaruh konvergensi IFRS, komite audit, dan kompleksitas perusahaan terhadap fee audit. Jurnal Akuntansi Bisnis, 151(29), 77-92. 